CLINICAL STUDY

\title{
The syndrome of gastric carcinoid and hyperparathyroidism: a family study and literature review
}

\author{
C Christopoulos $^{1,2}$, V Balatsos ${ }^{1,3}$, E Rotas ${ }^{1,2}$, I Karoumpalis ${ }^{1,3}$, D Papavasileiou ${ }^{1,2}$, G Kontogeorgos ${ }^{1,4}$, \\ S Dupasquier ${ }^{5}$, A Calender ${ }^{5}$, N Skandalis ${ }^{1,3}$ and P Economopoulos ${ }^{1}$ \\ ${ }^{1}$ The Greek MEN-1 Study Group and ${ }^{2}$ First Department of Internal Medicine, 'A. Fleming' General Hospital, Vas. Alexandrou 7, Kifissia, Athens 14561, \\ Greece, Departments of ${ }^{3}$ Gastroenterology and ${ }^{4}$ Pathology, 'G. Gennimatas' General Hospital, Athens 11527, Greece and ${ }^{5}$ Department of Genetics and \\ Cancer, University of Lyon, 69437 Lyon Cedex 03, France \\ (Correspondence should be addressed to C Christopoulos; Email: cgchrist@otenet.gr)
}

\begin{abstract}
Objective: To present evidence supporting the hypothesis that the coexistence of gastric carcinoids (GCs) and hyperparathyroidism may represent a distinct clinical entity, not related to multiple endocrine neoplasia type 1 (MEN1).

Methods: We studied a cohort of five young siblings (age range 26-42 years), one of whom had been found to have GC and hyperparathyroidism. All siblings underwent serial gastroscopies for the assessment of gastric neuroendocrine cell proliferations over a mean follow-up period of 31.2 months. Imaging, biochemical and hormonal as well as molecular genetic investigations were performed in the direction of MEN1 syndrome. The literature was searched for cases with coexistence of GCs and hyperparathyroidism not associated with MEN1.

Results: Four of the siblings, all male, were found to have GCs in a background of Helicobacter pyloriassociated chronic atrophic gastritis and pernicious anaemia, with no serological evidence of gastric autoimmunity. In two of them, asymptomatic hyperparathyroidism was also present. Screening for MEN1 gene mutations or large deletions was negative, and hormone and imaging investigations did not support a diagnosis of familial MEN1 syndrome. A literature search revealed sporadic reports of cases with GC and hyperparathyroidism not attributable to MEN1.

Conclusions: The association of GCs and hyperparathyroidism appears to constitute a distinct syndrome that can be encountered in genetically predisposed individuals, and should not be regarded as 'atypical' or 'incomplete' expression of MEN1. Its prevalence and aetiology should be the subject of future studies. Screening for hyperparathyroidism seems to be justified in patients with GC of any type.
\end{abstract}

European Journal of Endocrinology $160689-694$

\section{Introduction}

In recent years, well-differentiated gastric neuroendocrine tumors (carcinoids) have been diagnosed with increasing frequency as a result of the widespread availability of upper gastrointestinal endoscopy and the development of novel immunohistochemical protocols for the recognition of endocrine cells in gastric biopsies (1). Type I gastric carcinoids (GCs), seen in the setting of hypergastrinaemia associated with chronic atrophic gastritis (CAG), are the most common $(\sim 80 \%)$ gastric neuroendocrine tumors. They originate from the enterochromaffin-like (ECL) cells of the gastric body and fundus and their pathogenesis follows the sequence hyperplasia-dysplasia-neoplasia, in which gastrin plays a central role as trophic stimulus for ECL cell growth. A similar pathogenetic mechanism is thought to be operating in the rare $(\sim 5 \%)$ type II GCs that are ECL tumors associated with gastrinoma in the setting of multiple endocrine neoplasia type 1 syndrome (MEN1). The remaining (type III or 'sporadic') GCs are not associated with hypergastrinaemia and can originate from any endocrine cell of the gastric wall.

There have been sporadic reports of GCs coexisting with hyperparathyroidism (HPTH), where a diagnosis of MEN1 could not be substantiated (2-7). Although the possibility of 'atypical' or 'incomplete' MEN1 could not be theoretically excluded, the question was raised if such cases might represent a new association $(3,5)$. In the present study, we describe multiple cases of type I GCs in a family of five siblings with CAG, two of whom were also found to have HPTH. By contrast to type II GCs, multiple cases of which can occur in MEN1 families, familial occurrence of type I GCs appears to be exceedingly rare $(8,9)$. These cases evoke hypotheses to explain the association between gastric ECL cell and parathyroid proliferations. 


\section{Subjects and methods}

\section{Patients}

The index patient is the eldest of five siblings (four male, one female, age range 26-42 years). He was found to have a GC at age 38, when an upper gastrointestinal tract (GI) endoscopy was performed for investigation of persistent dyspepsia. He gave a history of a younger brother with dyspepsia and 'stomach polyps' discovered endoscopically at age 31 . Personal and family history was otherwise unremarkable. Routine biochemical investigations of the index patient revealed hypercalcaemia, hypophosphataemia and high plasma parathormone (PTH) levels, leading to a diagnosis of HPTH. In order to establish or exclude a diagnosis of MEN1 syndrome, all siblings gave informed consent to undergo endoscopic, imaging, hormone and genetic investigations.

\section{Upper GI endoscopy}

The siblings underwent upper GI endoscopy and all polypoid lesions detected were removed and examined histologically. Multiple biopsies from adjacent mucosa of the gastric fundus, corpus and antrum were also taken. Patients found to have ECL neoplasia or dysplasia were placed on a 6 monthly surveillance program with endoscopic removal of all subsequently appearing lesions.

\section{Histology and immunohistochemistry}

Gastric endocrine cell lesions were classified as: a) hyperplasia (simple, linear, micronodular, adenomatoid), b) dysplasia (enlarging or fusing micronodules, microinvasion, nodular growth) and c) neoplasia (carcinoid), according to the criteria of Solcia et al. (10). Despite its limitations, especially with regard to the definition of dysplasia (11), this classification offers clinical relevance without the need for expensive, cumbersome morphometric evaluations.

Immunohistochemical staining was carried out on formalin-fixed, paraffin-embedded sections by the onestep HRP polymer detection system, using a commercially available kit (Envision, Dako, Copenhagen, Denmark). The primary monoclonal antibodies or polyclonal sera applied were directed against chromogranin-A $(\mathrm{CgA})$, synaptophysin, serotonin, ghrelin, pancreatic polypeptide (PP), vasoactive intestinal peptide (VIP), somatostatin, gastrin, glucagon, insulin, cholecystokinin (CCK) and the proliferation-related antigen MKI67.

\section{Imaging}

Endoscopic ultrasonography (EUS) was employed for examination of the pancreas and gastric wall. The pituitary was examined with magnetic resonance imaging (MRI). Ultrasonography and/or scintigraphy with Tc99m-sestamibi were employed for imaging of parathyroid glands in patients with elevated plasma PTH levels. Bone density (femoral neck and lumbar spine) was measured with the dual-energy X-ray absorptiometry (DEXA) method. Whole-body octreoscan was performed using octreotide labelled with Indium-111.

\section{Hormonal and other assays}

Serum CgA levels were measured using a RIA kit (CISBIO, Bagnols-sur-Cèze, France). RIA kits were also used for the measurement of serum levels of gastrointestinal peptides including gastrin and glucagon (Siemens Medical Solutions Diagnostics, Tarrytown, NY, USA), somatostatin, PP, and VIP (Euro-Diagnostica, Arnhem, The Netherlands) and C-peptide (BioSource, Nivelles, Belgium), while insulin was measured by chemiluminescence using an IMMULITE 2000 Siemens analyser. Various commercially available kits were employed for measurement of prolactin, growth hormone, gonadotropins, adrenocorticotropin, PTH, calcitonin, thyroid stimulating hormone, free thyroxine, antithyroid antibodies (anti-TPO, anti-TG), anti-parietal cell antibodies (APCA), vitamin $\mathrm{B}_{12}$ and $25(\mathrm{OH})$-vitamin $\mathrm{D}_{3}$.

\section{Screening for MEN1 gene mutations}

DNA was extracted from peripheral blood leucocytes using a commercially available kit (QIAamp DNA Blood Mini Kit, Qiagen Inc). The coding exons (2-10) and respective splice junctions of the MEN1 gene were amplified by PCR and subjected to denaturing high performance liquid chromatography as described previously (12). The method has $100 \%$ sensitivity for mutation detection compared with direct sequencing. Quantitative multiplex PCR of short fluorescent fragments (QMPSF) was employed in order to exclude the presence of large deletions of one or more exons, and the products were analysed on PAGE using an automated Applied DNA sequencer system, according to previously published procedures (13).

\section{Results}

The main findings are summarized in Table 1. All four male siblings had similar gastroscopic appearances, characterized by multiple small $(<7 \mathrm{~mm})$ polyps of the body and fundus in a background of pangastritis with varying degrees of mucosal atrophy, intestinal metaplasia and chronic active inflammation. Histologically, most polyps were hyperplastic/inflammatory, but a significant proportion of them contained endocrine cell proliferations ranging from linear hyperplasia to neoplasia. Hyperplasia and occasionally dysplasia of endocrine cells was present in biopsies of the adjacent gastric mucosa. Small (not exceeding $5 \mathrm{~mm}$ in size), multifocal, well differentiated neuroendocrine tumors 
Table 1 Main findings in individual patients.

\begin{tabular}{|c|c|c|c|c|c|}
\hline & M-42 & F-40 & M-38 & M-37 & M-28 \\
\hline $\begin{array}{l}\text { Endoscopic } \\
\text { appearances }\end{array}$ & $\begin{array}{l}\text { Polyps body-fundus. } \\
\text { Erosive gastritis } \\
\text { antrum }\end{array}$ & $\begin{array}{l}\text { AG body-fundus. } \\
\text { Erythematous } \\
\text { gastritis antrum }\end{array}$ & $\begin{array}{l}\text { Polyps body-fundus. } \\
\text { AG body-fundus }\end{array}$ & $\begin{array}{l}\text { Polyps and AG } \\
\text { body-fundus. } \\
\text { Erosive gastritis } \\
\text { antrum }\end{array}$ & $\begin{array}{l}\text { Polyps body-fundus. } \\
\text { AG fundus }\end{array}$ \\
\hline $\begin{array}{l}\text { Most advanced ECL } \\
\text { cell lesion detected }\end{array}$ & Carcinoid & Linear hyperplasia & Carcinoid & Carcinoid & Carcinoid \\
\hline $\begin{array}{l}\text { Other histologic } \\
\text { findings }\end{array}$ & $\begin{array}{l}\text { Extensive CAG } \\
\text { with IM }\end{array}$ & $\begin{array}{l}\text { Chronic active } \\
\text { gastritis with IM }\end{array}$ & $\begin{array}{l}\text { Moderate CAG with } \\
\text { IM. Focal active } \\
\text { gastritis }\end{array}$ & $\begin{array}{l}\text { Chronic active } \\
\text { gastritis with IM }\end{array}$ & $\begin{array}{l}\text { Extensive CAG with } \\
\text { IM. Focal active } \\
\text { gastritis }\end{array}$ \\
\hline H. pylori infection & Yes & Yes & Yes & Yes & Yes \\
\hline Serum APCA & Absent & Absent & Absent & Absent & Absent \\
\hline $\begin{array}{l}\text { Serum gastrin } \\
(\mathrm{pg} / \mathrm{ml}) \mathrm{NR}:<110\end{array}$ & 1129 & 29 & 1108 & $>1263$ & $>1263$ \\
\hline $\begin{array}{l}\text { Serum B12 (pg/ml) } \\
\text { NR: } 200-900\end{array}$ & 89 & 486 & 173 & 151 & 99 \\
\hline $\begin{array}{l}\text { Serum CgA }(\mathrm{ng} / \mathrm{ml}) \\
\quad \text { NR: }<98\end{array}$ & 211 & 48 & 123 & 101 & 145 \\
\hline $\begin{array}{l}\text { Serum Ca (NR: 8.8- } \\
10.5 \mathrm{mg} / \mathrm{dl})\end{array}$ & 10.9 & 9.3 & 9.6 & 9.8 & 9.8 \\
\hline $\begin{array}{l}\text { Serum PTH }(\mathrm{pg} / \mathrm{ml}) \\
\text { NR: } 15-65\end{array}$ & 119 & 39 & 106 & 48 & 31 \\
\hline Other abnormalities & Simple goitre & Simple goitre & & Simple goitre & \\
\hline
\end{tabular}

M, male; F, female; AG, atrophic gastritis; CAG, chronic atrophic gastritis; IM, intestinal metaplasia; APCA, anti-parietal cell antibodies; CgA, chromogranin-A; $\mathrm{PTH}$, parathyroid hormone; NR, reference range.

(carcinoids) were found in the four male siblings (M-42, M-38, M-37, M-28). The tumors were seated deeply in the mucosa and were infiltrating the muscularis mucosae. Tumour cells were arranged in solid nodular or pseudoglandular formations, were $\mathrm{CgA}$ - and synaptophysin-positive, and showed low mitotic activity (MKI67 positivity $<2 \%$ ). No consistent immunoreactivity pattern for enteropancreatic peptides, serotonin and ghrelin was seen in the tumor cells. Focal hypoechogenic thickening of the deep mucosa was revealed by EUS in two cases (M-42, M-38), but the integrity of the gastric wall layers was well maintained in all cases and there was no evidence of tumor spread to lymph nodes or liver.

Persistently elevated levels of serum PTH were found in two siblings (M-42, M-38). In one of them (M-42) there was associated mild hypercalcaemia (ionized $\mathrm{Ca}=$ $1.38 \mathrm{mmol} / \mathrm{l}$ ) with hypophosphataemia (serum $\mathrm{P}=2.2 \mathrm{mg} / \mathrm{dl}$ ) and normal serum 25(OH)-vitamin $\mathrm{D}_{3}$ and calcitonin levels. Urinary calcium excretion while on a normal diet was increased $(426 \mathrm{mg} / 24 \mathrm{~h})$ in patient M-42, and borderline $(239 \mathrm{mg} / 24 \mathrm{~h})$ in patient M-38. DEXA T-scores were indicative of osteopenia in both patients. Tc99m-sestamibi scintigram revealed an area of hyperactive parathyroid tissue near the upper pole of the left lobe of the thyroid in patient M-42 but was negative in patient M-38. Ultrasonographic study in patient M-42 confirmed the presence of a mass with a maximum diameter of $16.5 \mathrm{~mm}$ and appearances compatible with a parathyroid adenoma behind the left upper pole of the thyroid. It also revealed a smaller nodule with similar ultrasonographic appearances behind the left lower pole, suggesting the presence of a second adenoma. There was no radiographic or ultrasonographic evidence of urolithiasis.

Pituitary and enteropancreatic hormone assays gave results within the reference range, apart from gastrin, the serum levels of which were elevated to more than 10 times the upper limit of normal in all siblings with ECL neoplasia. Serum CgA levels were also elevated in the hypergastrinaemic patients. A minute pituitary lesion ( $2 \mathrm{~mm}$ in diameter) with appearances compatible with a microadenoma was detected by MRI in one patient (M-42) but could not be seen on follow-up MRI performed 3 years later. A whole-body octreoscan performed in the same patient was negative. The rest of the imaging investigations in the direction of MEN1 gave negative results in all siblings. In particular, no pancreatic or adrenal lesions could be detected by EUS. Clinical examination for skin lesions associated with MEN1 (lipomas, angiofibromas, collagenomas) or polyglandular autoimmune syndrome (vitiligo) was also negative. A simple goitre was present in three of the siblings, all of whom were biochemically euthyroid and had no thyroid autoantibodies (anti-TG, anti-TPO). Screening for germline mutations of the coding region of the MEN1 gene was negative, as was the search for large deletions by QMPSF.

The average duration of follow-up was 31.2 months (range 24-36 months). All siblings received Helicobacter pylori eradication treatment, the success of which was confirmed histologically. The hypergastrinaemia persisted during the observation period in all siblings with ECL neoplasia, all of whom also developed vitamin $\mathrm{B}_{12}$ deficiency requiring parenteral cobalamin administration. Elevated serum $\mathrm{CgA}$ levels were not 
apparently affected by the systematic endoscopic removal of all newly appearing gastric polypoid lesions. During the same period, the HPTH remained asymptomatic in both cases.

\section{Discussion}

All five members of this unique sibship had gastric ECL cell proliferations of varying degrees, corresponding to the intensity of the associated atrophic gastritis. The latter could be aetiologically related to $H$. pylori infection, which often shows familial clustering. It is now recognized that long-standing $H$. pylori infection may lead to CAG and pernicious anaemia (PA) $(14,15)$, which should be differentiated from the classic autoimmune CAG. Moreover, there is evidence from studies in animals and humans that $H$. pylori infection may also lead to development of GCs, at least in certain ethnic groups (1-18). Proposed pathogenetic mechanisms involve the tropic stimulus of hypergastrinaemia and a possible direct mitogenic effect of $H$. pylori lipopolysaccharide on gastric ECL cells.

The development of HPTH in two out of four siblings with GC is unlikely to be caused by chance alone, due to the rarity of these conditions in young individuals. One has to postulate the presence of a specific genetic background predisposing to independent development of either condition, or, alternatively, a pathophysiological mechanism leading to the development of HPTH when a GC is present. The first hypothesis was adopted in some older reports of the combination of GC with HPTH, which was thought to represent an incomplete expression of MEN1 syndrome (2, 4-6). In fact, some of the reported cases had clinical features highly suggestive of MEN1(6). After the MEN1 gene was identified in 1997, it was shown that GC and HPTH could coexist outside the MEN1 setting (3). This is further supported by our negative genetic, biochemical and imaging investigations for MEN1 syndrome in this family with GC and HPTH. Apart from MEN1, familial predisposition to HPTH may also result from germline mutations in the genes for MEN2 (RET), familial hypocalciuric hypercalcaemia/neonatal severe HPTH (calcium-sensing receptor, $C A S R$ gene), HPTH - jaw tumor syndrome (CDC73), and familial isolated HPTH that has a mixed genetic basis. However, these conditions are not known to be associated with GC development. A literature search revealed five previous reports of HPTH associated with GC in patients not fulfilling the diagnostic criteria for MEN1 syndrome (2-6). Four of them occurred in patients with CAG/PA (Table 2).

It has been suggested that a mutation in exon 3 of the CTNNB1 gene, encoding $\beta$-catenin, may be involved in the oncogenesis of both carcinoids (19) and parathyroid tumors (20) through $\beta$-catenin accumulation and activation of the Wnt signalling pathway. However, the recently reported failure to detect CTNNB1 exon 3 mutations in large series of gastrointestinal (including gastric) carcinoids (21) and parathyroid ademonas (22) makes it unlikely that this mutation constitutes the genetic basis of ECL cell and parathyroid neoplasia in our family.

There is evidence that an unrecognized autoimmune mechanism might be participating in the pathogenesis of a proportion of cases of HPTH due to adenoma or hyperplasia (23). Moreover, it is known that H. pylori has the ability to trigger autoimmunity, possibly through mechanisms of molecular mimicry $(24,25)$. Therefore, despite the absence of APCA, an autoimmune mechanism leading to the development of both CAG and HPTH cannot be entirely exluded, in the view of lack of detailed gastric and parathyroid autoantibody studies in our patients and those reported by others.

As early as 1982, Selking et al. noted an increased prevalence of PA in 441 patients operated for primary HPTH (26), although the same authors could not find a

Table 2 Reported cases of hyperparathlyroidism (HPTH) associated with gastric carcinoid (GC) in the absence of multiple endocrine neoplasia type 1 (MEN1) syndrome.

\begin{tabular}{|c|c|c|c|c|}
\hline Sex/age ${ }^{a}$ & Associated conditions & Presentation of HPTH & Parathyroid pathology & Reference \\
\hline$M / 54$ & CAG/PA & Urolithiasis & Single adenoma & Alberti-Flor et al. (2) \\
\hline $\mathrm{F} / 50$ & CAG/PA & $\begin{array}{l}\text { Asymptomatic } \\
\text { hypercalcemia }\end{array}$ & Single adenoma & $\begin{array}{l}\text { Rode et al. }(6)^{\mathrm{b}} \text { and Stock- } \\
\text { brugger et al. }(7)^{\mathrm{b}}\end{array}$ \\
\hline $\mathrm{F} / 50$ & $\begin{array}{l}\text { CAG/PA, diabetes } \\
\text { mellitus type I, Graves' } \\
\text { disease }\end{array}$ & $\begin{array}{l}\text { Asymptomatic } \\
\text { hypercalcemia }\end{array}$ & Single adenoma & Ollenschlager et al. (5) \\
\hline $\mathrm{F} / 63$ & $\begin{array}{l}\text { CAG/PA, Hashimoto's } \\
\text { disease }\end{array}$ & $\begin{array}{l}\text { Asymptomatic } \\
\text { hypercalcemia }\end{array}$ & Single adenoma & Corleto et al. (3) \\
\hline $\mathrm{M} / 42$ & CAG/PA, goitre & $\begin{array}{l}\text { Asymptomatic } \\
\text { hypercalcemia }\end{array}$ & $\begin{array}{l}\text { Not operated. Imaging } \\
\text { studies suggest } \\
\text { adenoma }\end{array}$ & Present report \\
\hline$M / 38$ & CAG/PA & Asymptomatic & Not operated & Present report \\
\hline F/33 & - & Urolithiasis & Single adenoma & Nores et al. (4) \\
\hline
\end{tabular}

$\mathrm{M}$, male; F, female; CAG, chronic atrophic gastritis; PA, pernicious anaemia.

${ }^{a}$ At the time of diagnosis of HPTH.

${ }^{\mathrm{b}}$ Reports referring to the same patient. 
consistent relationship between serum gastrin levels and parathyroid hyperfunction in 32 patients with PA. Peracchi et al. reported HPTH in 3 out of 52 patients with CAG, 31 out of whom were also harbouring ECL cell proliferations (27). The fact that six out of the seven documented cases with GC and HPTH unrelated to MEN1 (Table 2) were seen in patients with hypergastrinaemia secondary to CAG evokes the question of whether gastrin could be playing a role in the pathogenesis of HPTH in these cases. A direct effect of gastrin on the parathyroids is unlikely, as gastrin receptors are typically absent from normal and neoplastic parathyroid tissue $(28,29)$. In chickens, hypergastrinaemia induced by administration of omeprazole or infusion of gastrin resulted in increased parathyroid gland weight and PTH gene expression (30). This is in contrast with the findings in fundectomised rats, where hypergastrinaemia had no effect on PTH (31). One would therefore be tempted to postulate that the ECL cells, absent in the case of fundectomy, are the link between gastrin and parathyroids. Histamine, the main product of ECL cells, has a known stimulatory effect on the parathyroids (32), and its serum levels can be found slightly elevated in patients with GC (8), although there is no evidence that this finding is clinically significant. It should be noted, however, that at least one other ECL cell product - basic fibroblast growth factor (NUDT6) - is known to exert a mitogenic effect on the parathyroids $(33,34)$. At variance with this hypothesis are the data of Gagnemo-Persson et al. (35), showing that stimulation of ECL cells by hypergastrinaemia in rats did not result in elevation of plasma PTH levels or PTH mRNA expression in the parathyroid gland.

It is theoretically conceivable that, in the setting of CAG, hyperparathyroidism might be reactive to calcitonin hypersecretion caused by stimulation of C-cells via their gastrin receptor (36). However, this mechanism is unlikely according to published data indicating that serum gastrin has no influence on calcitonin release in hypergastrinaemic patients with PA $(37,38)$.

Whatever the underlying mechanism, the evidence presented here points to the existence of an association between GC and HPTH, not attributable to MEN1. This association should be regarded as a syndrome seen mostly, but not exclusively in the clinical setting of CAG/PA. It is characterized by usually asymptomatic HPTH due to a parathyroid adenoma discovered incidentally during laboratory work-up of patients with GC. Future studies may establish the prevalence and elucidate the aetiology and clinical significance of this intriguing association. In the meantime, screening for HPTH seems justified in patients with GC of any type.

\section{Declaration of interest}

The authors declare no conflict of interest that could be perceived prejudicing the impartiality of this scientific work.

\section{Funding}

ICC, VB, ER, IK, DP, GK and NS are employees of the Greek National Health Service. Genetic studies were supported by the French CNRS network (no. 2906).

\section{References}

1 Modlin IM, Lye KD \& Kidd M. Carcinoid tumors of the stomach. Surgical Oncology 200312 153-172.

2 Alberti-Flor JJ, Halter S \& Dunn GD. Multiple gastric carcinoids in a patient with a history of primary hyperparathyroidism. American Journal of Gastroenterology $1985 \mathbf{8 0} 531-534$.

3 Corleto VD, Goebel SU, Panzuto F, Jensen RT, Delle Fave G \& Annibale B. Co-existence of hyperparathyroidism, hypergastrinaemia and multiple gastric carcinoids is not always due to incomplete expression of the MEN-1 syndrome. Digestive and Liver Disease 200335 585-589.

4 Nores JM, Dalayeun JF, Remy JM \& Nenna AD. Gastric carcinoid tumor and parathyroid adenoma. Gut 1988 29 689-690.

5 Ollenschläger G, Reincke M, Steffen M \& Allolio B. Unerkannter primärer hyperparathyreoidismus bei gleichzeitigem vorliegen eines insulinpflichtigen diabetes mellitus. gemeinsames vorkommen von nebenschiesddrüsenadenom, diabetes mellitus typ I, morbus basedow, perniziöser anämie und magenkarzinoid. Medizinische Klinik $1988 \mathbf{8 3} 844-5-854$.

6 Rode J, Dhillon AP, Cotton PB, Woolf A \& O'Riordan JL. Carcinoid tumor of stomach and primary hyperparathyroidism: a new association. Journal of Clinical Pathology $1987 \mathbf{4 0} 546-551$.

7 Stockbrugger RW, Menon GG, Beilby JO, Mason RR \& Cotton PB. Gastroscopic screening in 80 patients with pernicious anaemia. Gut 198324 1141-1147.

8 Hiroshi K, Yoshiya S, Makoto H, Hirofumi N, Keisi N, Keisuke I \& Hideaki E. Gastric carcinoid tumors in a brother-sister occurrence, with special reference to ultrastructural features of endocrine granules. Medical Electron Microscopy 1997 V30 228-234.

9 Yoshikane H, Nishimura K, Hidano H, Sakakibara A, Takahashi Y, Niwa Y \& Goto H. Familial occurrence of gastric carcinoid tumors associated with type A chronic atrophic gastritis. American Journal of Gastroenterology 199893 833-834.

10 Solcia E, Bordi C, Creutzfeldt W, Dayal Y, Dayan AD, Falkmer S, Grimelius L \& Havu N. Histopathological classification of nonantral gastric endocrine growths in man. Digestion $1988 \mathbf{4 1}$ 185-200.

11 Iwai K, Yao T, Nakamura S, Matsumoto T, Nishiyama K, Iida M \& Tsuneyoshi M. Multiple gastric carcinoids and endocrine cell micronests in type A gastritis: nuclear morphometric and immunohistochemical analysis. Oncology Reports 200513 397-404.

12 Crepin M, Pigny P, Escande F, Bauters CC, Calender A, Lefevre S, Buisine MP, Porchet N \& Odou MF. Evaluation of denaturing high performance liquid chromatography for the mutational analysis of the MEN1 gene. Journal of Molecular Endocrinology 200636 369-376.

13 Charbonnier F, Raux G, Wang Q, Drouot N, Cordier F, Limacher JM, Saurin J-C, Puisieux A, Olschwang S \& Frebourg T. Detection of exon deletions and duplications of the mismatch repair genes in hereditary nonpolyposis colorectal cancer families using multiplex polymerase chain reaction of short fluorescent fragments. Journal of Cancer Research 200060 2760-2763.

14 Annibale B, Lahner E, Bordi C, Martino G, Caruana P, Grossi C, Negrini R \& Delle Fave G. Role of Helicobacter pylori infection in pernicious anaemia. Digestive and Liver Disease 200032 756-762.

15 Kuipers EJ, Uyterlinde AM, Pena AS, Roosendaal R, Pals G, Nelis GF, Festen HP \& Meuwissen SG. Long-term sequelae of Helicobacter pylori gastritis. Lancet $1995 \mathbf{3 4 5} 1525-1528$.

16 Cao L, Mizoshita T, Tsukamoto T, Takenaka Y, Toyoda T, Cao X, Ban H, Nozaki K \& Tatematsu M. Development of carcinoid tumors 
of the glandular stomach and effects of eradication in Helicobacter pylori-infected mongolian gerbils. Asian Pacific Journal of Cancer Prevention $2008925-30$.

17 Chiba T. One more new gastric disease induced by Helicobacter pylori infection, enterochromaffin-like (ECL) cell carcinoid tumor. Journal of Gastroenterology 199934 545-546.

18 Sato Y, Iwafuchi M, Ueki J, Yoshimura A, Mochizuki T, Motoyama H, Sugimura K, Honma T, Narisawa R, Ichida T, Asakura H \& Van Thiel DH. Gastric carcinoid tumors without autoimmune gastritis in Japan: a relationship with Helicobacter pylori infection. Digestive Diseases and Sciences 200247 579-585.

19 Fujimori M, Ikeda S, Shimizu Y, Okajima M \& Asahara T. Accumulation of beta-catenin protein and mutations in exon 3 of beta-catenin gene in gastrointestinal carcinoid tumor. Cancer Research $2001616656-6659$.

20 Bjorklund P, Lindberg D, Akerstrom G \& Westin G. Stabilizing mutation of CTNNB1/beta-catenin and protein accumulation analyzed in a large series of parathyroid tumors of Swedish patients. Molecular Cancer 2008753.

21 Hervieu V, Lepinasse F, Gouysse G, Guillaud O, Barel C, Chambonniere ML, Bringuier PP, Poncet G, Lombard-Bohas C, Partensky C, Chayvialle JA \& Scoazec JY. Expression of betacatenin in gastroenteropancreatic endocrine tumors: a study of 229 cases. Journal of Clinical Pathology 200659 1300-1304.

22 Costa-Guda J \& Arnold A. Absence of stabilizing mutations of betacatenin encoded by CTNNB1 exon 3 in a large series of sporadic parathyroid adenomas. Journal of Clinical Endocrinology and Metabolism 200792 1564-1566.

23 Bjerneroth G, Juhlin C, Gudmundsson S, Rastad J, Akerstrom G \& Klareskog L. Major histocompatibility complex class II expression and parathyroid autoantibodies in primary hyperparathyroidism. Surgery $1998 \mathbf{1 2 4}$ 503-509.

24 Ma JY, Borch K, Sjostrand SE, Janzon L \& Mardh S. Positive correlation between $\mathrm{H}, \mathrm{K}$-adenosine triphosphatase autoantibodies and Helicobacter pylori antibodies in patients with pernicious anemia. Scandinavian Journal of Gastroenterology 1994 29 961-965.

25 Negrini R, Savio A \& Appelmelk BJ. Autoantibodies to gastric mucosa in Helicobacter pylori infection. Helicobacter 19972 S13-S16.

26 Selking O, Borch K, Johansson H, Ljunghall S \& Wide L. Evaluation of parathyroid function in patients with hypergastrinaemia and pernicious anaemia. Upsala Journal of Medical Sciences 198287 215-222.

27 Peracchi M, Gebbia C, Basilisco G, Quatrini M, Tarantino C, Vescarelli C, Massironi S \& Conte D. Plasma chromogranin A in patients with autoimmune chronic atrophic gastritis, enterochromaffin-like cell lesions and gastric carcinoids. European Journal of Endocrinology 2005152 443-448.
28 Dufresne M, Seva C \& Fourmy D. Cholecystokinin and gastrin receptors. Physiological Reviews 200686 805-847.

29 Reubi JC, Schaer JC \& Waser B. Cholecystokinin (CCK)-A and CCKB/gastrin receptors in human tumors. Cancer Research 199757 $1377-1386$.

30 Gagnemo-Persson R, Samuelsson A, Hakanson R \& Persson P. Chicken parathyroid hormone gene expression in response to gastrin, omeprazole, ergocalciferol, and restricted food intake. Calcified Tissue International 199761 210-215.

31 Rumenapf G, Schwille PO, Erben RG, Schreiber M, Berge B, Fries W, Schmiedl A, Koroma S \& Hohenberger W. Gastric fundectomy in the rat: effects on mineral and bone metabolism, with emphasis on the gastrin-calcitonin-parathyroid hormonevitamin D axis. Calcified Tissue International 199863 433-441.

32 Williams GA, Longley RS, Bowser EN, Hargis GK, Kukreja SC, Vora NM, Johnson PA, Jackson BL, Kawahara WJ \& Henderson WJ. Parathyroid hormone secretion in normal man and in primary hyperparathyroidism: role of histamine $\mathrm{H} 2$ receptors. Journal of Clinical Endocrinology and Metabolism 198152 122-127.

33 Bordi C, Falchetti A. Buffa R, Azzoni C, D'Adda T, Caruana P, Rindi G \& Brandi ML. Production of basic fibroblast growth factor by gastric carcinoid tumors and their putative cells of origin. Human Pathology 199425 175-180.

34 Komatsu M, Tsuchiya S, Matsuyama I, Kaneko S, Suzuki Y, Ito N, Hanamura N, Seki T, Kobayashi S \& Kuroda T. Expression of basic fibroblast growth factor in hyperplastic parathyroid glands from patients with multiple endocrine neoplasia type I. World Journal of Surgery 199418 921-924.

35 Gagnemo-Persson R, Persson P, Bryngelsson T, Green B \& Hakanson R. Rat stomach ECL-cell histidine decarboxylase activity is suppressed by ergocalciferol but unaffected by parathyroid hormone and calcitonin. Regulatory Peptides 1999 79 131-139.

36 Sorensen OH, Hindberg I \& Madsen SN. Secondary hyperparathyroidism in young rats given prolonged treatment with calcitonin. Acta Endocrinologica 197271 313-320.

37 Brandsborg M, Nielsen HE, Brandsborg O, Olsen KJ \& Lovgreen NA. The role of serum gastrin in the secretion of calcitonin: studies in patients with pernicious anaemia and in healthy subjects. Scandinavian Journal of Gastroenterology 198015 $23-28$.

38 Fahrenkrug J, Schaffalitzky de Muckadell OB \& Rehfeld JF. Serum calcitonin in hypergastrinaemia due to achlorhydria. Acta Endocrinologica 197786 140-145.

Received 19 December 2008

Accepted 13 January 2009 